\title{
FACTORS RELATED TO THE EVENT OF SIBLING RIVALRY IN CHILDREN 1-5 YEARS OLD IN LABIBIA SUB-DISTRICT OF MANDONGA DISTRICT IN KENDARI CITY
}

\author{
Islaeli Islaeli ${ }^{1}$, Anisa Purnamasari ${ }^{2}$, Sartina $^{3}$ \\ ${ }^{1,2,3}$ College of Health Sciences Mandala Waluya Kendari, Southeast Sulawesi, Indonesia. \\ Corresponding Author : Islaeli Islaeli \\ Email : islaeli.phd@gmail.com
}

\begin{abstract}
Background: Child psychological development is an important part of child welfare indicators. The development of child psychology determines the mental readiness of children, one of the problems in children's psychological development is sibling rivalry, which is a sense of competition due to the birth of a younger sibling, causing competition to get attention from their parents. Based on the initial survey, out of 8 mothers with children aged 1-5 years said that since the arrival of their new siblings, their first children often fuss and cry for no reason and want to always be noticed, sometimes even want to hit and injure their younger siblings. This study aims to determine the factors associated with the incidence of sibling rivalry in children aged 1-5 years in Labibia village, Mandonga sub-district, Kendari city.

Methods: The type of study was cross sectional design method. The sample in this study were all mothers who had two or more children aged 1-5 years in Labibia Village, Mandonga District, namely 39 mothers. The sampling technique used simple random sampling, the method of analysis used the Chi Square test.

Result: The results of this study, showed that there was a moderate relationship between knowledge and the incidence of sibling rivalry $\left(X^{2}\right.$ count $=6.955>$ the value of $X^{2}$ table $=$ $2.705)$ and the value of phi $(\varphi)=0.422$, there was a moderate relationship between parenting styles and the incidence of sibling rivalry $\left(X^{2}\right.$ Count $=8,269>$ the value of $X^{2}$ Table $\left.=2.705\right)$ and the value of phi $(\varphi)=0.460$ and there is a strong relationship between attitude and the incidence of sibling rivalry $\left(X^{2}\right.$ count $=18.373>$ value of $X^{2}$ Table $\left.=2.705\right)$ and the value of phi $(\varphi)=0.686$.

Conclusion: It is hoped that the parents further increase knowledge and awareness of the behaviors given and understanding of good parenting, with a good attitude will have a positive impact on their children.
\end{abstract}

Key words: Sibling rivalry incident, knowledge, parenting style, attitude, labibia village 


\section{INTRODUCTION}

Childhood is a period of growth and development starting from infants (0-1 years), playing age or toddlers (1-2.5 years), pre-school (2.5-5 years), school age (5-11 years). years), to adolescents (11-18 years). This range differs from one child to another given the different backgrounds of children. Children in the development process have physical, cognitive, self-concept, coping patterns and social behavior. Monitoring the psychological development of children up to pre-school age is one of the core competencies of nurses (1).

Child psychological development determines mental readiness in the next phase, namely adolescence and adults. One of the problems with children's psychological development is sibling rivalry. Sibling rivalry arises because of the attitudes and parenting patterns of parents towards their children, birth spacing that is too close, birth order in the family, the sex of the main siblings of the same sex, the number of siblings and the influence of other people. Forms of sibling rivalry include direct reactions and indirect reactions. Immediate reactions are such as hitting, pinching or kicking. Meanwhile, indirect behavior is such as making mischief, fussing, pretending to be sick, crying without cause, and doing habits or something that has not been done for a long time(2). Sibling rivalry usually occurs in childhood when the age difference between siblings is too close, namely the 3-5 year age range of preschool age and will reappear when the ages of 8-12 are school age. Usually sibling rivalry increases in preschool children (3-5 years) because at this time children tend to experience high jealousy if their parents give a little difference in attention to their siblings, at this time children's egocentrism is very high (3).

Sibling rivalry is a natural thing for families with more than one toddler, so parents are the key to the emergence of sibling. If parents are negligent and the child feels that they are not getting injustice or not getting attention, the child can take dangerous actions such as pushing his younger sibling out of bed. Therefore, some of the behaviors which can be done are giving affection and fair love for children, preparing older children to welcome the presence of a new sibling, giving punishment according to the child's mistakes not because of a golden child or not, sharing between parents and children, and pay attention to children's protests against parents' mistakes (4). Mother's knowledge and parenting style about sibling rivalry is very important in the development of a baby's personality. If the mother is unable to prevent it, the competition that occurs between children will remain and be carried over to adulthood. It is very important that the mother's knowledge about sibling rivalry and how to prevent and handle it, so that the competition that occurs becomes a positive thing, and helps the maturity of the child's social life and is able to solve problems in fierce competition (5).

Based on the results of previous research, there is the relationship between mother's knowledge of the incidence of sibling rivalry, where the level of knowledge of mothers on sibling rivalry in 31 toddlers $(48.4 \%)$ is very low. (6). Other studies have shown a relationship between parenting styles and the incidence of sibling rivalry in children aged 1-5 years (7). The attitude of parents in caring for children can also cause children to experience sibling rivalry, which is based on research that there is a significant relationship between the attitudes of parents and the occurrence of sibling rivalry in children aged 3-5 years. (4).

Based on the initial survey, beside of 8 mothers who had children aged 1-5 years said that since the arrival of a new younger sibling, their first child often fussed and cried for no reason and wanted to always be noticed, sometimes even wanted to hit and injure their younger siblings, fuss and cry for no reason, want to always pay attention and those who used to not wet the bed, wet themselves again. Based on the results of 
observations made by researchers, there are still many mothers who still compare their children, let their children do a fight and there are still many mothers who unknowingly put one child as the one who was defeated to break up a fight between siblings. This shows the lack of knowledge and the role of parents about sibling rivalry. This study aims to determine the factors associated with the incidence of sibling rivalry in children aged 1-5 years in Labibia village, Mandonga sub-district, Kendari city.

\section{METHOD}

This study uses a cross sectional design method. This research was conducted from May to June 2018. The sample in this study was 39 mothers in Labibia Village, Mandonga District, Kendari City. The sampling technique in this study used simple random sampling with the inclusion criteria of mothers who have two or more children aged 1-5 years. To see the relationship between variables, a Chi-Square test was performed.

\section{RESULT}

Table-1 shows that the 39 respondents, there were 17 respondents who had a sufficient level of knowledge, of which 9 respondents $(52.9 \%)$ had sufficient knowledge with no sibling rivalry and there were also 8 respondents $(47.1 \%)$ with sufficient knowledge level with sibling rivalry occurring. . Then there were 22 respondents who had less knowledge, then there were 3 respondents (13.6\%) who had a lack of knowledge with no sibling rivalry and 19 respondents $(86.4 \%)$ had a lack of knowledge with sibling rivalry.

Table- 2 shows that the 39 respondents, there were 16 respondents with good parenting, including 9 respondents $(56.2 \%)$ good parenting with no sibling rivalry and 7 respondents $(43.8 \%)$ good parenting with no sibling rivalry. Then there were 23 respondents with less parenting styles, including 3 respondents $(13.6 \%)$ less parenting with no sibling rivalry and 20 respondents $(87.0 \%)$ less parenting with sibling rivalry.

Table-3 shows that the 39 respondents, there were 16 respondents with positive attitudes including 11 respondents $(68.8 \%)$ positive attitudes with no sibling rivalry and there were 5 respondents $(31.2 \%)$ positive attitudes with no sibling rivalry. Then there were 23 respondents with negative attitudes, including 1 respondent $(4.3 \%)$ negative attitudes with no sibling rivalry and 22 respondents $(95.7 \%)$ negative attitudes with sibling rivalry occurring.

Table 1

The Relationship between Mother's Level of Knowledge and Sibling Rivalry inLabibiaSubdistrict, Mandonga District, Kendari City

\begin{tabular}{c|c|c|c|c|c|c|c}
\hline \multirow{2}{*}{$\begin{array}{c}\text { Level of } \\
\text { Mother's } \\
\text { Knowledge }\end{array}$} & \multicolumn{3}{|c|}{\begin{tabular}{c} 
Sibling Rivalry Incident \\
\cline { 2 - 6 }
\end{tabular}} & $\begin{array}{c}\text { Not sibling } \\
\text { rivalry }\end{array}$ & \multicolumn{2}{|c|}{$\begin{array}{c}\text { Sibling } \\
\text { rivalry }\end{array}$} & \multicolumn{2}{|c}{ Total } & $\begin{array}{c}\text { Chi Square } \\
X^{2} \text { Count> } \\
X^{2} \text { Table }\end{array}$ \\
\cline { 2 - 6 } & $\mathbf{n}$ & $\%$ & $\mathbf{n}$ & $\%$ & $\mathbf{n}$ & $\%$ & \\
\hline Well & 9 & 52,9 & 8 & 47,1 & 17 & 100 & $6,955>$ \\
Less & 3 & 13,6 & 19 & 86,4 & 22 & 100 & 2,705 \\
\hline Total & 12 & 30,8 & 27 & 69,2 & 39 & 100 & $\varphi=0,422$ \\
\hline
\end{tabular}


Table 2

The Relationship between Parenting Pattern and Sibling Rivalry inLabibiaSubdistrict, Mandonga District, Kendari City

\begin{tabular}{|c|c|c|c|c|c|c|c|}
\hline \multirow{3}{*}{$\begin{array}{l}\text { Parenting } \\
\text { Pattern }\end{array}$} & \multicolumn{4}{|c|}{ Sibling Rivalry Incident } & & \multirow[b]{2}{*}{ tal } & \multirow{3}{*}{$\begin{array}{c}\text { Chi Square } \\
X^{2} \text { Count }> \\
X^{2} \text { Table }\end{array}$} \\
\hline & \multicolumn{2}{|c|}{$\begin{array}{l}\text { Not sibling } \\
\text { rivalry }\end{array}$} & \multicolumn{2}{|c|}{$\begin{array}{l}\text { Sibling } \\
\text { rivalry }\end{array}$} & & & \\
\hline & n & $\%$ & $\mathbf{n}$ & $\%$ & $\mathbf{n}$ & $\%$ & \\
\hline Well & 9 & 56,2 & 7 & 43,8 & 16 & 100 & $8,269>$ \\
\hline Less & 3 & 13,6 & 20 & 87,0 & 23 & 100 & 2,705 \\
\hline Total & 12 & 30,8 & 27 & 69,2 & 39 & 100 & $\varphi=0,460$ \\
\hline
\end{tabular}

Table 3

The Relationship between Mother's Attitude and Sibling Rivalry inLabibiaSubdistrict, Mandonga District, Kendari City

\begin{tabular}{|c|c|c|c|c|c|c|c|}
\hline \multirow{3}{*}{$\begin{array}{c}\text { Mother's } \\
\text { Attitude }\end{array}$} & \multicolumn{4}{|c|}{ Sibling Rivalry Incident } & & \multirow[b]{2}{*}{ otal } & \multirow{3}{*}{$\begin{array}{c}\text { Chi Square } \\
X^{2} \text { Count }> \\
X^{2} \text { Table }\end{array}$} \\
\hline & \multicolumn{2}{|c|}{$\begin{array}{c}\text { Not sibling } \\
\text { rivalry }\end{array}$} & \multicolumn{2}{|c|}{$\begin{array}{l}\text { Sibling } \\
\text { rivalry }\end{array}$} & & & \\
\hline & $\mathbf{n}$ & $\%$ & n & $\%$ & $\mathbf{n}$ & $\%$ & \\
\hline Positive & 11 & 68,8 & 5 & 31,2 & 16 & 100 & $18,373>$ \\
\hline Negative & 1 & 4,3 & 22 & 95,7 & 23 & 100 & 2,705 \\
\hline Total & 12 & 30,8 & 27 & 69,2 & 39 & 100 & $\varphi=0,686$ \\
\hline
\end{tabular}

\section{DISCUSSION}

Knowledge is a very important domain for the formation of one's actions (ovent behavior). From experience and research, it turns out that behavior based on knowledge will be more sustainable than behavior that is not based on knowledge (5). Based on the research results, it shows that respondents who have a sufficient level of knowledge experience sibling rivalry. This is because the mother only knows about sibling rivalry, but she doesn't apply it to her children. Furthermore, respondents who have a low level of knowledge but do not experience sibling rivalry are due to the child's love and affection for their siblings. The results of this study are consistent with previous research which suggests that competition with siblings is a feeling of jealousy and hatred that a child usually experiences with the presence of his sibling. This feeling arises not because of hatred towards his new sibling, but rather from a change in situation or condition (6).
Parenting patterns are patterns of parental behavior that are applied to children that are relative and consistent over time. This pattern of behavior can be felt by children in negative and positive terms. Good parenting style will result in good children's behavior and also shape children's psychological development (8). Based on the results of the study, it shows that respondents who have good parenting styles but experience sibling rivalry because children often get influences from the outside environment such as television shows that contain elements of violence. Furthermore, respondents who have less parenting style but do not experience sibling because the child feels that siblings are friends to play and learn. This research is supported by previous research which states that applying authoritative parenting, parents with this type of parenting tend to be fairer to their children.(9). Parents better prepare their siblings to accept the presence of a new sibling, teach their children to share with each other, and teach children not to criticize 
or mock their friends. This shows that authoritative type parents tend to be more positive in caring for their children. Giving authority to children to express opinions so that children feel more valued(10).

Attitude is the most important concept in social psychology that discusses elements of attitude both as individuals and groups (10). Based on the results of the study, it shows that respondents who have a positive attitude but experience sibling rivalry, this is because children often get influences from their siblings who have negative attitudes such as wanting to be noticed and spoiled, causing the child to feel jealous. Furthermore, respondents who have a negative attitude but do not experience sibling rivalry are caused by children who really accept and love their siblings so they don't experience sibling rivalry. The results of previous research suggest that the attitude of parents in caring for children can cause children to experience sibling rivalry, so this theory can be proven by research. (9). The attitude of parents is very positive in caring for children, the incidence of sibling rivalry decreases, while the more negative attitudes of parents in caring for children, the incidence of sibling rivalry increases, and learning with peers is an effective strategy to solve problems in children (10).

\section{CONCLUSION}

Based on the research results, it can be concluded that there are there is a moderate relationship between knowledge, parenting styles and the incidence of sibling, and also there is a strong relationship between attitudes and the incident of sibling rivalry in Labibia Village, Mandonga District, Kendari City.

\section{REFERENCES}

1. Ministry of Health Republic of Indonesia. Health Data and Information Window Bulletin. Jakarta : Ministry of Health Republic of Indonesia; 2011.
2. McNerney, Usner, J. Sibling Rivalry in Degree and Dimensions Across the Lifespan. J Sci Wcp Muohio Edu [Internet]. 2001; Available from: www.usnerjm@muohio.edu

3. Woolfson R. Sibling Competition: Encouraging Children to Be Friends. Jkt Erlangga. 2004;(Translation of Fransiscus Rudianjo).

4. Maghfuroh. The relationship between parents' attitudes and the incidence of sibling rivalry in children aged 3-5 years in Brengkok-BrondongLamongan Village. Sci J Health Sci. 2012;X (1) hal 9-13.

5. Wawan. A, Dwi M. Knowledge, Attitudes and Human Behavior. Yogyakarta : Nuha medika; 2011.

6. Purnamasari D, Bakara, Derision Marsinova, Sutriyanti Y. Relationship between Mother's Knowledge Level and Sibling Rivalry Incidence at Toddler Age. Health J. 2014;V(2), Hal 182-188.

7. Rofi'ah S. Parenting Patterns for parents with the incidence of sibling rivalry in children aged 1-5 years. J Midwifery Sci. 2013;(1 (3)):152-9.

8. Rebar D, Bailey NW, Jarrett BJM, Kilner RM. An evolutionary switch from sibling rivalry to sibling cooperation, caused by a sustained loss of parental care. Proc Natl Acad Sci. 2020 Feb 4;117(5):2544-50.

9. Smith AL, Atwater DZ, Callaway RM. Early Sibling Conflict May Ultimately Benefit the Family. Am Nat. 2019 Oct;194(4):482-7.

10. Nofitasari A, Islaeli, Pratiwi DS, Said A, Risky S, Lestari SA. Knowledge and Attitude of Primary School Teacher on the Practice of Selected Food Students Containing Additional Hazardous Foodstuffs in Sdn 01 Poasia Kota Kendari. Indian J Public Health Res Dev. 2018;9(6):399. 